\title{
In vitro evaluation of shear bond strength of veneering ceramics to zirconia
}

\author{
Zeynep ÖZKURT ${ }^{1}$, Ender KAZAZOĞLU1 ${ }^{1}$ and Ahmet ÜNAL ${ }^{2}$ \\ ${ }^{1}$ Department of Prosthodontics, Faculty of Dentistry, Yeditepe University, Bagdat Cad. No: 238, Goztepe 34728, Istanbul, Turkey \\ ${ }^{2}$ Department of Metallurgy and Material Engineering, Faculty of Chemical-Metallurgy, Yıldız Technical University, Davutpasa Cad. 34220, Esenler, \\ Istanbul, Turkey \\ Corresponding author, Zeynep ÖZKURT; E-mail: zeynepozkurt@hotmail.com
}

\begin{abstract}
The bond strength between veneering ceramic and zirconia framework is the weakest link in the layered structure. To investigate the shear bond strength (SBS) of veneering ceramics to zirconia, four types of zirconia ceramics (Zirkonzahn, Cercon, Lava, DCZirkon) were selected. For each zirconia system, 30 disk specimens were layered with IPS e.max Ceram, Vita VM9, and a manufacturerrecommended veneering ceramic. SBS test was conducted, and fracture surface analysis was also performed to determine the failure modes. One-way ANOVA, two-way ANOVA, and Tukey's HSD tests were used to analyze the data. On shear bond strength between zirconia and their recommended veneering ceramics, statistically significant differences were observed among the different zirconia systems $(p<0.001)$. DC-Zirkon exhibited the highest SBS value $(40.49 \pm 8.43 \mathrm{MPa})$, followed by Lava $(27.11 \pm 2.72 \mathrm{MPa})$, Zirkonzahn $(24.46 \pm 3.72 \mathrm{MPa})$, and Cercon $(20.19 \pm 5.12 \mathrm{MPa})$. On shear bond strength to IPS e.max Ceram and Vita VM9, significantly lower values $(p<0.001)$ were observed for these veneering ceramics than their recommended veneering ceramics for DC-Zirkon and Lava. For Zirkonzahn and Cercon, similar SBS values were observed for all kinds of veneering ceramics $(p>0.05)$. In conclusion, the bonding of manufacturer-recommended veneering ceramic to the zirconia framework differed according to zirconia type.
\end{abstract}

Keywords: Delamination, Veneer, Zirconia

Received Jul 29, 2009: Accepted Oct 16, 2009

\section{INTRODUCTION}

Despite the success of metal-ceramic restorations in terms of strength and fracture resistance, the increased interest for improved esthetics has prompted researchers to investigate various new materials and techniques ${ }^{1)}$. In the last 10 years, core-veneered allceramic restorations have gained popularity among patients and clinicians ${ }^{2}$. This is chiefly because allceramic bilayered crowns have a potential to be more esthetically appealing than metal-ceramic restorations ${ }^{3)}$. Moreover, when the high strength of ceramic cores is combined with the superior esthetics of weaker veneering ceramics, reliable and more biocompatible restorations are attained ${ }^{4}$.

Presently, numerous materials are available as allceramic core materials: leucite-reinforced ceramics, glass-infiltrated ceramics, lithium disilicate, alumina, and zirconia ${ }^{5)}$. Amongst which, zirconia offers many unique qualities to render it as the core material of choice for fixed partial dentures (FPDs): high strength, transformation toughening mechanism, white appearance, chemical and structural stability ${ }^{6)}$. For these reasons, zirconia core material is strong enough to produce long-span, posterior, all-ceramic FPDs.

To achieve optimal esthetics, zirconia frameworks are veneered with a ceramic material. Then, adding veneer ceramics in layers provides the definitive restoration with individual optical characteristics ${ }^{7}$. While veneering zirconia frameworks with ceramics has been a boon to boost the esthetic appeal, the coreveneer interface is a bane as it contributes to ceramic chipping/cracking ${ }^{8}$, being one of the weakest aspects of zirconia-based restorations. To compound matters further, there remains a lack of thorough understanding on the zirconia-veneering ceramic relationship as not many clinical studies have been devoted to exploring the longevity of veneered zirconia $\mathrm{FPDs}^{9)}$. On the complication rates of veneered zirconia restorations, veneer chipping reportedly accounted for $15 \%$ in 24 months ${ }^{10)}, 13 \%$ in 36 months ${ }^{11)}$, and $25 \%$ in 31 months ${ }^{12)}$. It is also noteworthy that the failure rate of veneer chipping in veneered zirconia restorations was significantly higher than those of metal-ceramic systems, namely $0.4 \%$ for single-tooth metal-ceramic restorations ${ }^{13)}$ and $2.9 \%$ for FPDs after 36 months ${ }^{14)}$. These cohesive fractures chiefly stemmed from the inadequate mechanical properties of the veneering ceramics.

In metal-ceramic systems, excessive stresses that arise from coefficient of thermal expansion (CTE) mismatch may be compensated to some extent by plastic or elastic deformation of the metallic framework ${ }^{15)}$. However, unlike metals, the zirconia framework has a higher rigidity and this feature causes more destructive stress to be formed in the veneer layer of zirconia-based restorations. Against this background, the strength of the veneering ceramic is a crucial parameter for long-term clinical success ${ }^{16)}$. For metal-ceramics, it has been suggested by Craig and Powers ${ }^{17)}$ that an adequate bond occurs when the fracture stress is greater than $25 \mathrm{MPa}$. However, for all-ceramic restorations, no suggestions have been put forth with regard to the adequate bond strength. In some studies, the shear bond strength (SBS) between metal alloys and porcelain has been found to range between 61.40 and 96.80 $\mathrm{MPa}^{18-20)}$. For core-veneered all-ceramic restorations, previous investigations 
indicated that the core-veneer bond strength ranged between $16 \mathrm{MPa}$ and $42 \mathrm{MPa}^{2,21-23)}$.

With all-ceramic dental prostheses, their clinical success and reliability hinges on the mechanical integrity and adhesion strength of the interface between the veneering ceramic and the ceramic core. As for the cause of veneering ceramics delaminating from the zirconia cores, multiple factors are involved. These factors are namely: CTE mismatch between core and ceramic, firing shrinkage of ceramic, poor wetting by veneering on core, and undesired heating and cooling rates ${ }^{24)}$.

To achieve strong adhesion, the veneering ceramic is generally fused to the core at high temperatures. However, fusion can introduce significant residual stresses in both layers if CTE matching is not satisfied $^{25,26)}$. In a study by Guazzato et al. ${ }^{27)}$, it was found that CTE mismatch resulted in a region of high stress above the ceramic-core interface and became more pronounced at higher CTE mismatch between the core and the veneering ceramic. Consequently, a crack initiated and propagated in the vicinity of the interface in the veneering ceramic. This phenomenon indicates that zirconia has a relatively lower CTE than most other ceramic materials. Against this background, special veneer ceramics that have lower or same CTE as zirconia have been developed by manufacturers to minimize this unfavorable complication of veneer chipping/cracking ${ }^{21)}$.

The purpose of this study was to investigate and compare the bond strengths of commercial zirconia framework materials with their manufacturerrecommended veneering ceramics against other commercially available veneering ceramic materials. This study was carried out using SBS test as well as fracture surface analysis to microscopically characterize the failure modes. The null hypothesis tested was that the bond strength between zirconia and its manufacturer-recommended veneering ceramic will be higher than other commercially available veneering ceramics which can be used for zirconia frameworks.

\section{MATERIALS AND METHODS}

\section{Preparation of zirconia core specimens}

Four types of zirconia-based ceramics were selected for this study: Zirkonzahn (Steger, Ahrntal, Italy), Cercon (DeguDent, Hanau, Germany), Lava (3M ESPE, Seefeld, Germany), and DC-Zirkon (DCS Dental AG, Allschwil, Switzerland). With each zirconia system, 30 disk-shaped specimens of $7 \mathrm{~mm}$ diameter and $3 \mathrm{~mm}$ height were fabricated.

For Zirkonzahn, Cercon, and Lava, pre-sintered zirconium oxide blocks were milled according to the manufacturers' instructions. Then, they were cleaned, dried, and sintered according to the suggested firing schedules (Table 1). For DC-Zirkon, fully sintered zirconium oxide blocks were milled according to the manufacturer's instructions.

The bonding surfaces of zirconia core specimens were polished consecutively with 600-, 800-, and 1200grit silicon carbide papers (English Abrasives, London, England) under water-cooling on a polishing machine (Phoenix Beta Grinder/Polisher, Buehler, Germany) to obtain standardized surface roughness. Then, airborne particle abrasion was applied on the bonding surfaces with $120-\mu \mathrm{m}$ aluminum oxide $\left(\mathrm{Al}_{2} \mathrm{O}_{3}\right)$ particles for 15 seconds at 3.5 bar pressure and at $10-\mathrm{mm}$ distance from the surface. Finally, the disk specimens were both ultrasonically cleaned in 96\% isopropyl alcohol for 3 minutes and steam-cleaned for 10 seconds.

Table 1 Zirconia systems evaluated in this study and their firing schedules

\begin{tabular}{lllcr}
\hline Core material & \multicolumn{1}{c}{ Manufacturer } & Lot number & Sintering temperature & Sintering time \\
\hline Zirkonzahn & Steger, Ahrntal, Italy & ZA50026B & $1,500^{\circ} \mathrm{C}$ & 16 hours \\
Cercon & DeguDent, Hanau, Germany & 20021827 & $1,350^{\circ} \mathrm{C}$ & 6 hours \\
Lava & 3M ESPE, Seefeld, Germany & 254920 & $1,500^{\circ} \mathrm{C}$ & 7.5 hours \\
DC-Zirkon & DCS Dental AG, Allschwil, Switzerland & G0707Z10 & - & - \\
\hline
\end{tabular}

Table 2 Properties of veneering materials as provided by the manufacturers

\begin{tabular}{llcc}
\hline Veneer material & \multicolumn{1}{c}{ Manufacturer } & Flexural strength (MPa) & CTE* \\
\hline Ice Keramik & Steger, Ahrntal, Italy & Not provided & Not provided \\
Cercon Ceram & DeguDent, Hanau, Germany & 80 & 9.2 \\
Lava Ceram & 3M ESPE, Seefeld, Germany & 100 & $9.8-10$ \\
TriCeram & Esprident, Ispringen, Germany & 81 & $8.7-9.0$ \\
IPS e.max Ceram & Ivoclar Vivadent, Liechtenstein & $90 \pm 10$ & 9.5 \\
VM9 & Vita Zahnfabrik, Bad Säckingen, Germany & 96 & $8.8-9.2$ \\
\hline
\end{tabular}

* Coefficient of Thermal Expansion in $10^{-6} / \mathrm{K}$ between 25 and $500^{\circ} \mathrm{C}$. 
Table 3 Firing schedules of the veneering ceramics according to manufacturers

\begin{tabular}{|c|c|c|c|c|c|}
\hline \multicolumn{6}{|c|}{ Liner } \\
\hline Veneering Ceramic & Temperature $\left({ }^{\circ} \mathrm{C}\right)$ & $\begin{array}{l}\text { Time } \\
(\min )\end{array}$ & $\begin{array}{l}\text { Heating rate } \\
\left({ }^{\circ} \mathrm{C} / \mathrm{min}\right)\end{array}$ & $\begin{array}{l}\text { Firing temperature } \\
\qquad\left({ }^{\circ} \mathrm{C}\right)\end{array}$ & $\begin{array}{l}\text { Holding time } \\
\text { (min) }\end{array}$ \\
\hline Ice Keramik & 350 & 5 & 55 & 920 & 2 \\
\hline Cercon Ceram & 450 & 8 & 60 & 850 & 1 \\
\hline Lava Ceram & 450 & 4 & 45 & 840 & 1 \\
\hline TriCeram & 500 & 4 & 65 & 800 & 1 \\
\hline IPS e.max Ceram & 400 & 4 & 60 & 960 & 1 \\
\hline Vita VM9 & 500 & 6 & 55 & 930 & 1 \\
\hline \multicolumn{6}{|c|}{ Dentin } \\
\hline Veneering Ceramic & Temperature $\left({ }^{\circ} \mathrm{C}\right)$ & $\begin{array}{l}\text { Time } \\
(\min )\end{array}$ & $\begin{array}{l}\text { Heating rate } \\
\left({ }^{\circ} \mathrm{C} / \mathrm{min}\right)\end{array}$ & $\begin{array}{l}\text { Firing temperature } \\
\qquad\left({ }^{\circ} \mathrm{C}\right)\end{array}$ & $\begin{array}{l}\text { Holding time } \\
\text { (min) }\end{array}$ \\
\hline Ice Keramik & 300 & 6 & 55 & 820 & 1 \\
\hline Cercon Ceram & 450 & 6 & 60 & 840 & 1 \\
\hline Lava Ceram & 450 & 6 & 45 & 810 & 1 \\
\hline TriCeram & 500 & 6 & 55 & 760 & 2 \\
\hline IPS e.max Ceram & 400 & 4 & 50 & 750 & 1 \\
\hline Vita VM9 & 500 & 6 & 55 & 910 & 1 \\
\hline
\end{tabular}

\section{Preparation of core-veneer specimens}

For each zirconia system, the disk specimens were divided into three subgroups of 10 specimens each according to the type of veneering ceramic used. Ten specimens of each zirconia system were veneered with their manufacturer-recommended veneering ceramic (Ice Keramik, Cercon Ceram, Lava Ceram, or Triceram), and the remaining specimens equally divided for two types of commercial veneering ceramics which can be used for any zirconia framework (IPS e.max Ceram and Vita VM9) (Table 2).

Using a specially-designed, separable stainless steel mold, a prepared zirconia disk specimen was placed in the mold where clearance of $5 \mathrm{~mm}$ diameter and $3 \mathrm{~mm}$ height was available above the core material for condensing the veneer ceramic. The veneering procedure was performed using the manual layering technique. First, the liner material, which was a single, thin, continuous layer supplied by the manufacturers, was applied and fired independently according to the manufacturer's instructions (Table 3). After firing the liner, the veneering porcelain powder was mixed with the manufacturer-supplied condensing liquid and condensed using the vibration blotting technique. The obtained slurry was blotted with tissue to eliminate excess water and then condensed into the mold.

The prepared core-veneer disks were fired in a programmable vacuum porcelain furnace (Vita Vacumat 4000 Premium T, Vita Zahnfabrik, Bad Säckingen, Germany) according to the firing programs provided by the manufacturers (Table 3). Owing to firing shrinkage, the exact diameter of the veneer layer

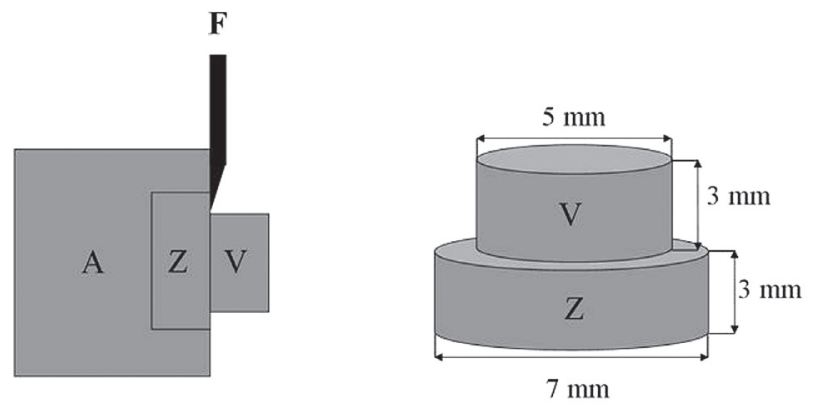

Fig. 1 Illustration of shear bond strength test setup and specimen preparation, where $\mathrm{Z}$ : zirconia ceramic, $\mathrm{V}$ : veneering ceramic, A: acrylic resin.

of the specimens was measured with a micro-measuring device (Mitutoyo Digimatic Caliper, Mitutoyo Corp., Kawasaki, Japan) before SBS testing. The minimum reading value of the caliper was set at $\pm 0.001 \mathrm{~mm}$.

\section{Shear bond strength (SBS) test}

By means of an acrylic resin (Meliodent, Heraeus Kulzer GmbH, Hanau, Germany), each specimen was embedded at the center of a metal ring holder, $13 \mathrm{~mm}$ in height and $15 \mathrm{~mm}$ in diameter, with the core-veneer interface positioned at the top level of the holder. All specimens were stored in distilled water at $37^{\circ} \mathrm{C}$ for 24 hours before testing.

After 24-hour water storage, these metal holders were mounted in a universal testing machine (Model 3345, Instron Corp., Norwood, MA, USA). Specimens 
were tightened and stabilized to ensure that the 1-mmthick edge of the shearing device was in contact with the core surface and was positioned as close as possible to the veneer-core interface (Fig. 1). Shear load was applied at a crosshead speed of $1 \mathrm{~mm} / \mathrm{min}$ until fracture occurred. The ultimate load to failure was recorded in Newton (N). As for the average shear bond strength (MPa), it was calculated by dividing the load $(\mathrm{N})$ at which failure occurred by the bonding area $\left(\mathrm{mm}^{2}\right)$ as follows:

Shear stress $(\mathrm{MPa})=\operatorname{Load}(\mathrm{N}) /$ Area $\left(\mathrm{mm}^{2}\right)$;

where Area $=\left(\pi \times d^{2}\right) / 4\left(\mathrm{~mm}^{2}\right)$;

where $d=$ exact diameter of the bonding surface

As for the mean failure load and standard deviation for each group, they were calculated from these data.

\section{Fracture surface analysis}

The fractured surfaces were visually analyzed with a dental operating microscope (OPMI pico, Carl Zeiss, Essen, Germany; $\times 25$ magnification) to determine the failure modes of specimens. Failure modes were classified as follows: cohesive fracture within the veneer, adhesive fracture between the core and veneer, or a combination of both.

\section{Statistical analysis}

One-way analysis of variance (ANOVA) was used to test the differences in SBS between zirconia ceramics and their manufacturer-recommended veneering ceramics. Multiple comparisons among zirconia materials which were bonded to their recommended veneering ceramics were made with Tukey's HSD (Honestly Significant Difference) test. Furthermore, one-way ANOVA was used to test the differences in SBS among all the veneering ceramics within each zirconia group and to compare the SBS of the recommended ceramic against the other commercially available veneering ceramics. Two-way ANOVA was used to analyze the effects of zirconia, veneering ceramic, and their interaction on SBS. An alpha level of 0.05 was used for all statistical analyses, which were performed using a statistical software (SPSS ver 10.0, SPSS Inc., Chicago, IL, USA).

\section{RESULTS}

Shear bond strength

Table 4 summarizes the mean values and standard deviations of SBS for all the tested zirconia ceramics and veneering ceramics. On SBS with their manufacturer-recommended veneering ceramics (Table

Table 4 Mean shear bond strength values and standard deviations (SD) in MPa ( $n=10)$, and failure modes in percentage $(\%)$

\begin{tabular}{|c|c|c|c|c|}
\hline Zirconia ceramics & Veneering ceramics & Mean & $\mathrm{SD}$ & Failure modes \\
\hline \multirow[t]{3}{*}{ Zirkonzahn } & Ice Keramik & 24.46 & 3.72 & $\begin{array}{l}50 \% \text { adhesive } \\
50 \% \text { combined }\end{array}$ \\
\hline & IPS e.max Ceram & 26.04 & 4.01 & $\begin{array}{l}50 \% \text { adhesive } \\
50 \% \text { combined }\end{array}$ \\
\hline & Vita VM9 & 26.52 & 6.32 & $100 \%$ combined \\
\hline \multirow[t]{3}{*}{ Cercon } & Cercon Ceram & 20.19 & 5.12 & $\begin{array}{l}80 \% \text { adhesive } \\
20 \% \text { combined }\end{array}$ \\
\hline & IPS e.max Ceram & 24.17 & 4.54 & $\begin{array}{l}50 \% \text { adhesive } \\
50 \% \text { combined }\end{array}$ \\
\hline & Vita VM9 & 21.67 & 7.80 & $100 \%$ combined \\
\hline \multirow[t]{3}{*}{ Lava } & Lava Ceram & 27.11 & 2.72 & $\begin{array}{l}30 \% \text { adhesive } \\
70 \% \text { combined }\end{array}$ \\
\hline & IPS e.max Ceram & 23.05 & 4.88 & $\begin{array}{l}60 \% \text { adhesive } \\
40 \% \text { combined }\end{array}$ \\
\hline & Vita VM9 & 18.66 & 2.73 & $\begin{array}{l}50 \% \text { adhesive } \\
50 \% \text { combined }\end{array}$ \\
\hline \multirow[t]{3}{*}{ DC-Zirkon } & TriCeram & 40.49 & 8.43 & $\begin{array}{l}50 \% \text { adhesive } \\
50 \% \text { combined }\end{array}$ \\
\hline & IPS e.max Ceram & 21.38 & 5.99 & $\begin{array}{l}50 \% \text { adhesive } \\
50 \% \text { combined }\end{array}$ \\
\hline & Vita VM9 & 31.51 & 8.15 & $100 \%$ combined \\
\hline
\end{tabular}


5), one-way ANOVA revealed significant differences among the zirconia groups $(p<0.001)$. Further, Tukey's HSD test showed that there were significant differences between DC-Zirkon and the other zirconia materials $(p<0.001)$ (Table 6), and that the highest mean SBS was recorded for DC-Zirkon bonded to TriCeram.

For all the three types of veneering ceramics within each zirconia group, their SBS differences were analyzed with one-way ANOVA. Within Zirkonzahn and Cercon groups, there were no significant differences in mean SBS among the three veneering ceramic subgroups $(p>0.05)$ (Tables 7 and 8$)$. However, the analysis data for Lava and DC-Zirkon were different from those of Zirkonzahn and Cercon. Within Lava group, there were significant differences in mean SBS among the three veneering ceramics $(p<0.001)$ (Table 9). In particular, Lava Ceram exhibited a significantly higher SBS value than IPS e.max Ceram and Vita
VM9. Within DC-Zirkon group, there were also significant differences in mean SBS among the veneering ceramics $(p<0.001)$ (Table 10). In particular, TriCeram exhibited a significantly higher SBS than IPS e.max Ceram and Vita VM9.

Table 11 summarizes the statistical analysis results on the effects of zirconia, veneering ceramic, and their interaction on SBS. Two-way ANOVA revealed that the factors of zirconia $(p<0.001)$ and veneering ceramic $(p<0.01)$, and their interaction $(p<0.001)$, had a significant effect on SBS.

\section{Fracture modes}

Table 4 presents the fracture analysis results in percentage. None of the test groups demonstrated cohesive failure within the veneer. With Vita VM9 veneer, Zirkonzahn, Cercon, and DC-Zirkon specimens demonstrated $100 \%$ combined failure. As for the

Table 5 One-way ANOVA results on the shear bond strength values of zirconia specimens and their recommended veneering ceramics

\begin{tabular}{lcrccc}
\hline & Sum of squares & df & Mean square & F-Ratio & Significance \\
\hline Between groups & 2305.947 & 3 & 768.649 & 25.95 & $<0.001^{*}$ \\
Within groups & 1066.062 & 36 & 29.613 & & \\
Total & 3372.010 & 39 & & & \\
\hline
\end{tabular}

Table 6 Tukey's HSD test among the zirconia materials bonded to their recommended veneering ceramics

\begin{tabular}{lcccc}
\hline \multicolumn{1}{c}{ Zirconia groups } & Mean difference & Significance & Lower bound & Upper bound \\
\hline DC-Zirkon/Cercon & 20.314 & $<0.001^{*}$ & 13.7597 & 26.8683 \\
Lava/Cercon & 6.920 & 0.035 & 0.3657 & 13.4743 \\
Zirkonzahn/Cercon & 4.278 & 0.310 & -2.2763 & 10.8323 \\
DC-Zirkon/Lava & 13.394 & $<0.001^{*}$ & 6.8397 & 19.9483 \\
DC-Zirkon/Zirkonzahn & 16.036 & $<0.001^{*}$ & 9.4817 & 22.5903 \\
Lava/Zirkonzahn & 2.642 & 0.700 & -3.9123 & 9.1963 \\
\hline
\end{tabular}

Table 7 One-way ANOVA results on the shear bond strength values of Zirkonzahn with all the veneering ceramics

\begin{tabular}{lccccc}
\hline & Sum of squares & df & Mean square & F-Ratio & Significance \\
\hline Between groups & 23.181 & 2 & 11.591 & 0.497 & 0.614 \\
Within groups & 629.821 & 27 & 23.327 & & \\
Total & 653.002 & 29 & & & \\
\hline
\end{tabular}

Table 8 One-way ANOVA results on the shear bond strength values of Cercon with all the veneering ceramics

\begin{tabular}{lccccc}
\hline & Sum of squares & df & Mean square & F-Ratio & Significance \\
\hline Between groups & 80.989 & 2 & 40.494 & 1.128 & 0.338 \\
Within groups & 969.036 & 27 & 35.890 & & \\
Total & 1050.024 & 29 & & & \\
\hline
\end{tabular}


Table 9 One-way ANOVA results on the shear bond strength values of Lava with all the veneering ceramics

\begin{tabular}{lccccc}
\hline & Sum of squares & df & Mean square & F-Ratio & Significance \\
\hline Between groups & 356.615 & 2 & 178.308 & 13.851 & $<0.001^{*}$ \\
Within groups & 347.590 & 27 & 12.874 & \\
Total & 704.205 & 29 & & \\
\hline
\end{tabular}

Table 10 One-way ANOVA results on the shear bond strength values of DC-Zirkon with all the veneering ceramics

\begin{tabular}{lccccc}
\hline & Sum of squares & df & Mean square & F-Ratio & Significance \\
\hline Between groups & 1829.881 & 2 & 914.941 & 15.842 \\
Within groups & 1559.395 & 27 & 57.755 & & $<0.001^{*}$ \\
Total & 3389.276 & 29 & & \\
\hline
\end{tabular}

Table 11 Two-way ANOVA results on the effects of zirconia, veneering ceramic, and their interaction on shear bond strength

\begin{tabular}{|c|c|c|c|c|c|}
\hline Source & Sum of squares & $\mathrm{df}$ & Mean square & $\mathrm{F}$ & Significance \\
\hline Corrected Model & 3804.88 & 11 & 345.90 & 10.66 & $<0.001^{*}$ \\
\hline Intercept & 77652.54 & 1 & 77652.55 & 2392.14 & $<0.001^{*}$ \\
\hline zirconia & 1514.22 & 3 & 504.74 & 15.55 & $<0.001 *$ \\
\hline veneer & 430.74 & 2 & 215.37 & 6.63 & $<0.01^{*}$ \\
\hline zirconia * veneer & 1859.93 & 6 & 309.99 & 9.55 & $<0.001^{*}$ \\
\hline Error & 3505.84 & 108 & 32.46 & & \\
\hline Total & 84963.27 & 120 & & & \\
\hline Corrected Total & 7310.72 & 119 & & & \\
\hline $\mathrm{A}$ & \multicolumn{5}{|c|}{$\mathrm{R}$ Squared $=0.520($ Adjusted R Squared $=0.472)$} \\
\hline
\end{tabular}

zirconia group of Cercon, $80 \%$ adhesive failure was demonstrated when veneered with Cercon Ceram.

\section{DISCUSSION}

Based on the results obtained, the proposed hypothesis was accepted for two zirconia ceramics, DC-Zirkon and Lava. They showed higher bond strength with their recommended veneering ceramics, as compared to IPS e.max Ceram and Vita VM9. On the other hand, Cercon and Zirkonzahn did not show any significant differences in bond strength among the three types of veneering ceramics; hence the proposed hypothesis was rejected for these two zirconia ceramics.

Effect of core-veneer bond strength on delamination and fracture patterns

When pitted against metal-ceramic bonding, zirconiaveneer bond strength is comparatively lower ${ }^{18-20}$. Indeed, SBS values obtained in the present study ranged between 18.66 and $40.49 \mathrm{MPa}$, which were similar to previous studies ${ }^{2,21-23)}$. Nonetheless, in previous studies on the chipping and delamination of veneering ceramics from zirconia frameworks, these occurrences were not solely nor directly associated with weak core-veneer bond strength ${ }^{10)}$.

In a study that focused on the fractographic analysis of fractured ceramic FPDs ${ }^{5}$, it was found that crack propagation in zirconia-based FPDs was different from that in lithia-disilicate-based FPDs, whereby the crack propagated immediately in the latter. Although the core layer was tougher than the veneer, the crack did not arrest or deviate out of the original propagation plane once crack propagation began in the veneer. As for the fracture in zirconia-based FPDs, which also initiated from the veneer, it behaved differently from that in lithia-disilicate-based FPDs because it stopped at the interface. Owing to the weaker interfacial adhesion and the greater fracture toughness of zirconia, the crack stopped, turned and propagated along the interface. It was thus found that interfacial delamination in veneer-zirconia ceramic structures controlled the fracture initiation sites and failure stresses of the zirconia core. In addition, the design 
and dimension of the connectors as well as the span size of FPDs can be key factors in causing fractures at lower occlusal loads but due to high fracture stresses ${ }^{5)}$.

Adhesive failure does not occur in the presence of a good bond between compatible ceramic core and veneering materials ${ }^{23)}$. In the present study, specimens of all the test groups revealed adhesive and combined failures between the zirconia cores and their veneering ceramics, but no incidence of cohesive failure within the veneer (Table 4). In particular for Vita VM9, Zirkonzahn, Cercon and DC-Zirkon groups applied with this veneering ceramic showed $100 \%$ combined failures. It could thus be concluded that zirconia type was not a decisive factor in the fracture pattern, since Vita VM9 veneer ceramic resulted in combined failures with three types of zirconia materials.

\section{Effect of bond strength test method on bond strength values}

The core-veneer bond strength of all-ceramic systems has been assessed using different bond strength test methods. In a study that employed the microtensile bond strength (MTBS) test method $^{2)}$, an intriguingly low MTBS at 29.1 $\pm 13.7 \mathrm{MPa}$ was noted between the zirconia framework and its recommended veneer ceramic. This low MTBS value stood in contrast to the higher MTBS values obtained for other core materials with their recommended veneering ceramics, such as that of $44.6 \pm 9.1 \mathrm{MPa}$ obtained for lithium disilicate core material.

In the same vein, when MTBS test was used to assess the core-veneer bond strength of Cercon-Cercon Ceram, bond strength values of 29.10 $13.70 \mathrm{MPa}$ and $26.30 \pm 8.6 \mathrm{MPa}^{2,21)}$ were reported by Aboushelib et al. These values were higher than the $20.19 \pm 5.12 \mathrm{MPa}$ obtained in the present investigation for Cercon group. These differences in bond strength values could be explained by the use of SBS test in this study, instead of the MTBS test employed by Aboushelib et al..$^{2,21)}$. Indeed, when SBS test was used by Al-Dohan et al. ${ }^{23)}$ to investigate the bond strength of DC-Zirkon ceramic core to Vita D veneer, an SBS value of $27.90 \pm 4.79 \mathrm{MPa}$ was obtained, which was comparable to that obtained in the present investigation $(31.51 \pm 8.15 \mathrm{MPa})$.

\section{Effects of zirconia core and veneering ceramic materials on bond strength}

Apart from bond strength test method, differences in bond strength values could also be attributed to the type of veneering ceramic used with the zirconia framework. In a study by Aboushelib et al. ${ }^{22)}$, Cercon Ceram Express (press-on veneering ceramic) exhibited a bond strength value of $37.9 \pm 5.1 \mathrm{MPa}$ with the Cercon framework, which was higher than the 20.18 $\pm 5.12 \mathrm{MPa}$ obtained in this study for Cercon Ceram (layering veneer ceramic). Hence, a key reason for this difference in bond strength lay in the use of press-on veneering ceramic versus the layering veneer ceramic.

Gleaning from the results of both published literature and the present study, it seemed to indicate that core-veneer bond strength is sensitive to a multitude of interacting variables. One of the affecting variables is the type of veneering ceramic used, which has been found to influence both the bond strength and the esthetic outcome ${ }^{7)}$. Another affecting variable is the type of zirconia core material. In the present study, the bond strengths of DC-Zirkon and Lava with their manufacturer-recommended veneering ceramics, TricCeram and Lava Ceram respectively, were higher than with IPS e.max Ceram and Vita VM9. A twofold reason accounted for these differences in bond strength values. On one hand, it was due to the different structural characteristics of the veneering ceramics tested - in terms of composition, strength, CTE, or firing shrinkage. On the other hand, the different surface characteristics of the zirconia core materials in terms of grain size, shape, composition, density, and hardness - also affected the bond strength value of the final structure ${ }^{22)}$.

Further on the influence of the type of zirconia material on core-veneer bond strength, it is noteworthy that for the DC-Zirkon system, fully sintered HIP zirconia blocks were milled. This meant increases in both the mechanical properties and bonding performance, which then led to the highest SBS values exhibited by DC-Zirkon with TriCeram and Vita VM9 at $40.49 \pm 8.43 \mathrm{MPa}$ and $31.51 \pm 8.15 \mathrm{MPa}$ respectively. On the other hand, for Zirkonzahn, Cercon, and Lava systems, presintered non-HIP zirconia blocks were milled and then sintered. Therefore in a sharp contrast, Vita VM9 veneering ceramic applied to Lava exhibited the lowest bond strength at $18.66 \pm 2.73 \mathrm{MPa}$.

As for Zirkonzahn and Cercon, the SBS values obtained with their recommended veneering ceramics were in the same range as those of commercially available veneering ceramics. Hence, if Zirkonzahn and Cercon were the preferred core materials for the framework, they may be applied with either their manufacturer-recommended veneering ceramics or other commercially available veneering ceramics. However, if DC-Zirkon and Lava were the preferred core materials, it is highly expedient that they can be used with their recommended veneering ceramics for reduced chipping or delamination risk and enhanced clinical success.

Effects of test method and test protocol on bond strength To date, diverse test methodologies have been used to assess core-veneer bond strength, ranging from shear bond strength (SBS) test, microtensile bond strength (MTBS) test, to three- and four-point loading tests and biaxial flexural strength test. Each test method has its suite of advantages and disadvantages ${ }^{2)}$.

For the SBS test, it is defined as a test in which two materials are connected via an adhesive agent and loaded in shear until separation occurs ${ }^{17)}$. Bond strength is calculated by dividing the maximum applied force by the bonded cross-sectional area. SBS tests have been widely used primarily because of its relative simplicity of use, as compared to MTBS tests ${ }^{28)}$. Other 
advantages of the SBS test method include ease of specimen preparation, clear test protocol, and rapid production of test results ${ }^{29)}$.

Despite the seemingly many advantages as given above, some critical aspects must be taken into account when using an in vitro method to estimate the clinical performance of materials. First, in vitro information cannot be used as a direct, straightforward prediction for the clinical situation. Secondly, large variations exist in in vitro test results ${ }^{29)}$. In the case of the SBS test method, a concerted effort must be made to standardize the test method so as to improve the clinical usefulness of this in vitro test. Further, other important aspects that must be considered during an SBS test include storage conditions, type of specimen used and the preparation method, rate of load application, cross-sectional surface area, and the researcher's experience. To the end of resolving some of these issues, the International Organization for Standardization established parameters and guiding principles on shear bond strength measurement in 1994

In the present study, all the test specimens were stored in distilled water at $37^{\circ} \mathrm{C}$ for 24 hours before testing. The effects of thermal cycling and long-term storage on bond strength were not evaluated in this study, and this could be considered as a limitation. Although long-term storage is important in the simulation of clinical conditions, bond strength results of short-term in vitro tests may provide substantial and helpful leverage for evaluation of clinical conditions. On this premise, the results of this study would be beneficial for the comparison of different veneering materials and zirconia ceramics in future researches, which should then include evaluation using the thermal cycling method.

\section{CONCLUSIONS}

Within the limitations of this study, the following conclusions were drawn:

1. Bond strength between zirconia core and veneer was affected by the types of zirconia and veneering materials used.

2. On bonding with manufacturer-recommended veneering ceramics, significantly higher bond strengths were observed for DC-Zirkon and Lava zirconia groups. As for Cercon and Zirkonzahn zirconia groups, there were no significant differences in bond strength among the three tested veneering ceramic materials.

3. Amongst all the obtained SBS data, the two highest SBS values were obtained with DCZirkon, which was produced from fully sintered zirconia blocks.

4. Surface analysis of the fracture surfaces revealed that the predominant failure modes between zirconia core and the veneer were combined and adhesive failures. No cohesive failures were observed.

\section{REFERENCES}

1) Fischer H, Marx R. Fracture toughness of dental ceramics: comparison of bending and indentation method. Dent Mater 2002; 18: 12-19.

2) Aboushelib MN, de Jager N, Pallav P, Feilzer AJ. Microtensile bond strength of different components of core veneered all-ceramic restorations. Dent Mater 2005; 21: 984-991

3) O’Brien WJ. Dental materials and their selection, 3rd ed, Quintessence, Chicago, 2002, pp. 200-209.

4) Lawn BR, Deng Y, Thompson VP. Use of contact testing in the characterization and design of all-ceramic crown-like layer structures: a review. J Prosthet Dent 2001; 86: 495510 .

5) Taskonak B, Yan J, Mecholsky JJ Jr, Sertgöz A, Koçak A. Fractographic analyses of zirconia-based fixed partial dentures. Dent Mater 2008; 24: 1077-1082.

6) Guazzato M, Albakry M, Ringer SP, Swain MV. Strength, fracture toughness and microstructure of a selection of allceramic materials. Part II. Zirconia-based dental ceramics. Dent Mater 2004; 20: 449-456.

7) Aboushelib MN, Kleverlaan CJ, Feilzer AJ. Microtensile bond strength of different components of core veneered allceramic restorations. Part III: Double veneer technique. J Prosthodont 2008; 17: 9-13.

8) Aboushelib MN, de Jager N, Kleverlaan CJ, Feilzer AJ. Effect of loading method on the fracture mechanics of two layered all-ceramic restorative systems. Dent Mater 2007; 23: 952-959.

9) Donovan TE. Metal-free dentistry. J Esthet Restor Dent 2005; 17: 141-143.

10) Vult von Steyern P, Carlson P, Nilner K. All-ceramic fixed partial dentures designed according to the DC-Zircon technique. A 2-year clinical study. J Oral Rehabil 2005; 32: 180-187.

11) Sailer I, Fehér A, Filser F, Lüthy H, Gauckler LJ, Schärer P, Franz Hämmerle CH. Prospective clinical study of zirconia posterior fixed partial dentures: 3-year follow-up. Quintessence Int 2006; 37: 685-693.

12) Raigrodski AJ, Chiche GJ, Potiket N, Hochstedler JL, Mohamed SE, Billiot S, Mercante DE. The efficacy of posterior three-unit zirconium-oxide-based ceramic fixed partial dental prostheses: a prospective clinical pilot study. J Prosthet Dent 2006; 96: 237-244.

13) Pjetursson BE, Sailer I, Zwahlen M, Hammerle CHF. A systematic review of the survival and complication rates of all-ceramic and metal-ceramic reconstructions after an observation period of at least 3 years. Part I: single crowns. Clin Oral Implant Res 2007; 18: 73-85.

14) Sailer I, Pjetursson BE, Zwahlen M, Hammerle CHF. A systematic review of the survival and complication rates of all-ceramic and metal-ceramic reconstructions after an observation period of at least 3 years. Part II: fixed dental prostheses. Clin Oral Implant Res 2007; 18: 86-96.

15) Anusavice KJ, Carroll JE. Effect of incompatibility stress on the fit of metal-ceramic crowns. J Dent Res 1987; 66: 1341-1345.

16) Fischer J, Stawarczyk B, Hammerle CHF. Flexural strength of veneering ceramics for zirconia. J Dent 2008; 36: 316-321.

17) Craig RG, Powers JM. Restorative dental materials, $11^{\text {th }}$ ed, Mosby, St. Louis, 2002, pp. 85, 551-592.

18) Ashkanani HM, Raigrodski AJ, Flinn BD, Heindl H, Mancl LA. Flexural and shear strengths of $\mathrm{ZrO}_{2}$ and a high-noble alloy bonded to their corresponding porcelains. J Prosthet Dent 2008; 100: 274-284.

19) Akova T, Ucar Y, Tukay A, Balkaya MC, Brantley WA. Comparison of the bond strength of laser-sintered and cast 
base metal dental alloys to porcelain. Dent Mater 2008; 24: 1400-1404.

20) Joias RM, Tango RN, Junho de Araujo JE, Junho de Araujo MA, Ferreira Anzaloni Saavedra Gde S, Paes-Junior TJ, Kimpara ET. Shear bond strength of a ceramic to $\mathrm{Co}-\mathrm{Cr}$ alloys. J Prosthet Dent 2008; 99: 54-59.

21) Aboushelib MN, Kleverlaan CJ, Feilzer AJ. Microtensile bond strength of different components of core veneered allceramic restorations. Part II: Zirconia veneering ceramics. Dent Mater 2006; 22: 857-863.

22) Aboushelib MN, Kleverlaan CJ, Feilzer AJ. Effect of zirconia type on its bond strength with different veneer ceramics. J Prosthodont 2008; 17: 401-408.

23) Al-Dohan HM, Yaman P, Dennison JB, Razzoog ME, Lang BR. Shear strength of core-veneer interface in bi-layered ceramics. J Prosthet Dent 2004; 91: 349-355.

24) De Jager N, Pallav P, Feilzer AJ. The influence of design parameters on the FEA-determined stress distribution in CAD-CAM produced all-ceramic dental crowns. Dent Mater 2005; 21: 242-251.
25) Taskonak B, Mecholsky JJ Jr, Anusavice KJ. Fracture surface analysis of clinically failed fixed partial dentures. J Dent Res 2006; 85: 277-281.

26) Hermann I, Bhowmick S, Lawn BR. Role of core support material in veneer failure of brittle layer structures. $J$ Biomed Mater Res B 2007; 82: 115-121.

27) Guazzato M, Proos K, Quach L, Swain MV. Strength, reliability and mode of fracture of bi-layered porcelain/ zirconia (Y-TZP) dental ceramics. Biomaterials 2004; 25: 5045-5052.

28) Oilo G. Bond strength testing - what does it mean? Int Dent J 1993; 17: 492-498.

29) Hadavi F, Hey JH, Ambrose ER, Louie PW, Shinkewski DJ. The effect of dentin primer on the shear bond strength between composite resin and enamel. Oper Dent 1993; 18: 61-65.

30) International Organization for Standardization. ISO TR 11405, Dental materials - Guidance on testing of adhesion to tooth structure, 1994. 